\title{
A study of phonological issues in the text variants of Xiaochu and Dachu hexagrams, Zhouyi
}

\begin{abstract}
This paper discusses some phonological issues with the Xiaochu (小畜) and Dachu (大畜) hexagrams by using text variants from three versions of the unearthed Zhouyi (周易). We point out that the reading of the character 輻 fú 'spoke', which rhymes with 目 mù 'eye' in the current version of Xiaochu, is the result of phonetic assimilation. We also propose that the phonetic 逐 zhú 'pursue' be assigned to the *-uk group instead of *-iwk in the BaxterSagart (2014) system.
\end{abstract}

Keywords: Old Chinese language; Zhouyi hexagrams; Chinese rhymes; phonological reconstruction.

The third line statement (爻辭) of the current version of the Xiaochu hexagram in Zhouyi (周易·小畜) has the following passage: “九三, 興說輻, 夫妻反目” ${ }^{1}$. Commentators from Han to Wei periods proposed diverse interpretations for the word 輻 fú: both Wang Bi's Zhouyi zhu (王貆, 周易注) and Yu Fan's Zhouyi zhu (盧翻, 周易注) noted that 輻fú represents the wheel spoke of a chariot, while Ma Rong (馬融) and Zheng Xuan (鄭玄) had another version which used the character 輹 fù instead. According to Ma and Zheng, 輹 fù is a component of the chariot which connects the axle with the compartment (車伏兔) ${ }^{2}$. The textual variation between 輻 $f^{\prime} u$ and 輹 fù also triggers certain phonological issues which will be discussed in this paper.

During the Song and Ming dynasties, philologists usually followed Wang Bi's version. For instance, in his Zhouyi benyi (周易本義)，Zhu Xi (朱喜) explained “畽說輻” as “spokes detach from the wheel" ${ }^{3}$. During the Qing dynasty, however, while using Old Chinese rhyming analysis, scholars became suspicious about the character 輻 fú in Wang Bi's version. In Yi Yin, Yinxue Wushu (音學五書·易音), Gu Yanwu (顧炎武) examined all of the rhyming passages in the Zhouyi and pointed out that 輻 fú does not rhyme regularly in the Xiaochu (小畜) line statements. He noted:

The character 輻 rhymes with 側, 直, 億, 特, 食 in Fa tan, Shi Jing (詩 • 伐檀, 112.2A), with 載 and 意 in Zhengyue (正月, 192.10A)，with 塞 and 息 from quotations of lost Shi (逸詩) in Yunzi (荀子); whereas 目 mù rhymes with 腹 and 復 in The second year of duke Xuan, Zuozhuan (左傳 - 宣二年), with 䠩 in The sixteenth year of duke Cheng (成公十六年). One cannot force 輻 to rhyme with 目, hence 輹 should be the correct version in the Xiaochu hexagram (The first volume of Yi Yin, Yinxue Shishu) ${ }^{4}$.

Acknowledgments: The research leading to this paper has received funding from Science Foundation of Ministry of Education of China - Youth Project (NO.17YJC740066). I would like to thank Prof. Shen Ruiqing and Prof. George Starostin for their detailed suggestions and corrections. All faults are mine.

1 "The third NINE, undivided, suggests the idea of a carriage, the strap beneath which has been removed, or of a husband and wife looking on each other with averted eyes."

2 This paper deals only with phonological issues; we will address the controversial statements in the commentaries elsewhere.

3 有輿說輻之象。

4 “輻”字《詩・伐檀》與“側” “直”“億”“特”“食”韻, 《正月》與“載”“意”韻， 《荀子》引逸《詩》與“塞”“息”韻； “目”字 《左・宣二年》與 “腹” “復” 韻, 《成十六年》與“躆”韻。不可強合也, 作“輹”為是(顧炎武《音學十書. 易音. 卷一》)。 
Gu believed that 目 mù in the Xiaochu line statement originally rhymed with 輹 fù, and that the character 輻 $f^{\prime}$ in the current version was due to text corruption. Gu's opinion was later adopted by many other scholars, such as Duan Yucai (段玉裁), Jiang Yougao (江有誥), Wang Niansun (王念孫), etc. Their detailed rhyming analyses are as follows ${ }^{5}$ :

Table 1. Rhyming patterns of Xiaochu

\begin{tabular}{|c|c|c|c|c|}
\hline \multicolumn{5}{|c|}{ Xiaochu(小畜) line statements } \\
\hline & $\mathrm{Gu}$ & Duan & Jiang & Wang \\
\hline 初九：復自道A，何其昷A，吉。 & $\circ$ & $\circ$ & $\circ$ & $\circ$ \\
\hline 九二：牽復B，吉。 & & \multirow{2}{*}{$\circ$} & & \multirow{2}{*}{$\circ$} \\
\hline 九三：動說輻[輹]B, 夫妻反且B。 & o & & o & \\
\hline 六四：有孚, 血去惕出, 无各。 & & & & \\
\hline 九五：有孚攣如, 富以其鄰。 & & & & \\
\hline 上九：既雨C既處 $C$, 尚德載, 婦貞庽。月幾望, 君子征凶。 & $\circ$ & $\circ$ & & $\circ$ \\
\hline
\end{tabular}

Duan, Jiang and Wang agree with Gu Yanwu that 輻 fú in the current version should be revised to 輹 fù. Jiang Yougao's analysis coincides with Gu in linking the rhyming words 輹 fù and 目 mù. Apart from that, Duan Yucai and Wang Niansun recognize 復 fù 'return' in the second line as a rhyme word along with 輹 fù 'wedge' and 目 mù. We follow Duan and Wang's opinion.

Qing scholars sometimes quoted commentaries from Ma Rong and Zheng Xuan, in which an alternate text variant 輿說輹 from Xiaochu was preserved. Shuowen also features the same quotation 輿脫輹, but it is hard to determine whether it is from Xiaochu (小畜) or Dachu (大畜). The rhyming contexts in the Dachu hexagram are as follows:

Table 2. Rhyming patterns of Dachu

\begin{tabular}{|c|c|c|c|c|}
\hline \multicolumn{5}{|c|}{ Dachu (大畜) line statements } \\
\hline & $\mathrm{Gu}$ & Duan & Jiang & Wang \\
\hline 初九：有庽，利己。 & & & & \\
\hline 九二：䑖說輹A。 & & \multirow{3}{*}{$\circ$} & & \multirow{3}{*}{ ○ } \\
\hline 九三：良馬逐 $\mathrm{A}$, 利艱貞。日閒輿衛, 利有做往。 & & & & \\
\hline 六四：童牛之牿B，元吉。 & & & & \\
\hline 六五：豶豕之牙B，吉。 & & \multirow{2}{*}{$\circ$} & & \multirow{2}{*}{ ○ } \\
\hline 上九：何天之矔B，亨。 & & & & \\
\hline
\end{tabular}

Neither Gu Yanwu nor Jiang Yougao had identified the rhyming pattern in the second and third line statements. Both Duan Yucai and Wang Niansun pointed out that 輹 fù 'wedge' rhymes with 逐 zhú 'pursue', and that 牿 gù 'livestock' rhymes with 牙 yá 'tooth' and 忂 qú 'broad street'. Here we follow Duan and Wang's analyses.

The phrase 輿說輻 can further be compared to the Dazhuang (大壯) hexagram. The rhyming situations are as follows:

${ }^{5}$ Rhyme words are marked with underlining; A, B, C represent different rhyme groups. 
Table 3. Rhyming patterns of Dazhuang.

\begin{tabular}{|c|c|c|c|c|}
\hline \multicolumn{5}{|c|}{ Dazhuang (大壯) line statements } \\
\hline & $\mathrm{Gu}$ & Duan & Jiang & Wang \\
\hline \multicolumn{5}{|l|}{ 初九：壯于趾，征凶，有孚。 } \\
\hline \multicolumn{5}{|l|}{ 九二：貞吉。 } \\
\hline 九三：小人用娤 $\mathrm{A}$, 君子用国 $\mathrm{A}$, 貞厲。羝羊觸藩, 贏其角。 & $\circ$ & o & & o \\
\hline \multicolumn{5}{|l|}{ 九四：貞吉悔亡，藩決不羸，壯于大興之輹。 } \\
\hline \multicolumn{5}{|l|}{ 六五：喪羊于易，无悔。 } \\
\hline 上六：羝羊觸藩，不能退B，不能遂B，无做利 $\mathrm{B}$, 艱則吉。 & ○ & ० & & o \\
\hline
\end{tabular}

Jiang did not identify the rhyming patterns in Dazhuang (大壯). Duan believed that 壯 zhuàng rhymed with 罔 wăng in the third line and that 退 tuì rhymed with 遂 suì and 利 $l i ̀$ in the sixth line statement; Gu and Wang agreed with Duan, except that they believed that 利 $l i$ did not rhyme, due to certain inherent features of Zhouyi (周易): divinatory idioms such as “good fortune” (吉), “bad fortune” (凶), “disappearance of repentance” (悔亡) and so on should be excluded from the line statements, hence they do not rhyme under any circumstances. As for the character 輹 fù, it is commonly agreed that it does not rhyme in this hexagram.

There are now several unearthed pieces of evidence supporting the revision of 輹 fù. Three versions of unearthed Zhouyi are available to us: 1) Shangbo version (上博本), which is written on bamboo strips, dated to the late Warring States period (312-221 BC); 2) Fuyang version (阜陽本), also written on bamboo strips, dated to the late Western Han period (206 BC 9 AD); 3) Boshu version (帛書本), which is written on silk, also dated to the late Western Han. Their preservation situation varies greatly: Boshu version contains all sixty-four hexagrams, including the hexagram's name (卦名), the hexagram statement (彖辭), and six line statements (爻辭), as well as parts of “Ten Wings” (十翼), such as Xici (繫辭) and even texts that were lost in history, including Er san zi (二三子), Yi zhi yi (易之义), Yao (要), Miuhe (缪和), Zhaoli (昭力); Shangbo version contains about half of the sixty-four hexagrams with no Ten Wings attached; Fuyang version is severely damaged, with hexagram fragments found only occasionally ${ }^{6}$.

The characters 輹 fù or 輻 fú in the current versions indeed find their correlations in these unearthed versions of the Zhouyi ${ }^{7}$ :

Boshu Xiaochu (少(小)㥗(畜), upper line 84)：

(1) 九二：堅(率)復, 吉。

九三 : 車說緮, 夫妻反目。

'The second NINE, undivided, shows its subject, by the attraction (of the former line), returning (to the proper course). There will be good fortune. ${ }^{8}$

The third NINE, undivided, suggests the idea of a carriage, the <strap > (wedge) beneath which has been removed, or of a husband and wife looking on each other with averted eyes.'

Here 緮 fù corresponds to 輻 fú in the current version; in Shangbo and Fuyang Zhouyi, however, this hexagram has been lost. The character 緮 fù has the same phonetic component as 輹 fü, which fits well with Qing scholars' prediction. According to the principle of “tong sheng

${ }^{6}$ For details, see Han Ziqiang (韓自強) 2004, Ma Chengyuan (馬承源) 2003, and Qiu Xigui (永錫圭) 2014.

${ }^{7}$ For now, we only deal with text variants which are associated with rhyming activities.

${ }^{8}$ This paper uses James Legge (2013)'s English translation of Zhouyi, with several modifications. 
bi tong bu” (同聲必同部), since 輹 fù and 緮 fù share the same phonetic they must have had an identical or close pronunciation in the Old Chinese period.

Shangbo Dachu (上博本大筑(畜), third volume, strip 20) has:

(2) 九二：車(攽)說复。

九晶(三)：良馬由(逐)，利堇(艱)貞。曰班車衛，利有做往。

“The second NINE, undivided, shows a carriage with the strap under it removed.

The third NINE, undivided, shows its subject urging his way with good horses.”

Whereas the Boshu version of Dachu (泰 (大) 蓄 (畜), line 11) has:

(3) 九二 : 車說緮。

九三：良馬逐，利根(艱)貞。曰闌(閑)車衛，利有做往。

(refer to the previous translation)

Here 复 fù and 緮 fù correspond to 輹 fù in the current version. Their pronunciation in the Old Chinese period is also close since they share the same phonetic component.

Boshu Dazhuang (泰 (大) 壯, line 33) has:

(4) 九四：貞吉悔亡，䊩(藩)块不贏，壯于大車之緮。

"The fourth NINE, undivided, shows (a case in which) firm correctness leads to good fortune, and occasion for repentance disappears. (We see) the fence opened without the horns being entangled. The strength is like that in the wheel-spokes of a large wagon.”

Here 緮 fù corresponds to 輹 fù in the current version. This hexagram has been lost in both Shangbo and Fuyang Zhouyi.

Connecting the rhyming words above, we have the following table:

Table 4. Rhyming behaviors of 輹 fù in various versions of Zhouyi.

\begin{tabular}{|c|c|c|c|c|}
\hline & Rhyme group & OC & $\mathrm{MC}$ & Notes \\
\hline 復 fù & 覺 & *m-puk & bjuwk & \\
\hline 目 $m \grave{u}$ & 覺 & ${ }^{*}$ C.muk & mjuwk & \\
\hline 輹 fù & 覺 & ${ }^{*} \mathrm{~m}$-puk & bjuwk & \\
\hline 緮 fù & 覺 & -- & -- & Boshu Xiaochu and Dachu \\
\hline 复 fù & 覺 & ${ }^{*} \mathrm{~m}$-puk & bjuwk & Shangbo Dachu \\
\hline 輻 fú & 職 & *pok & pjuwk & The current version of Xiaochu \\
\hline 逐 zhú & 覺 & *lriwk & drjuwk & The current version and Boshu Dachu \\
\hline 由 yóu & 幽 & ${ }^{*} l u$ & yuw & Shangbo Dachu \\
\hline
\end{tabular}

There are two irregular rhyming behaviors in the table above, all of which are related to the Middle Chinese rhyme -juwk (屋韻三等). According to the reconstruction of Baxter, Sagart (2014) as well as other "six vowel" systems, -juwk has several Old Chinese origins, and they merged mainly under the influence of initial consonants (see below).

The first issue is that 輻 fú ( ${ }^{*}$ pok) in the current version of Xiaochu (小畜) should not rhyme with characters from group *-uk (覺部) or group * ${ }^{*}$ (幽部).

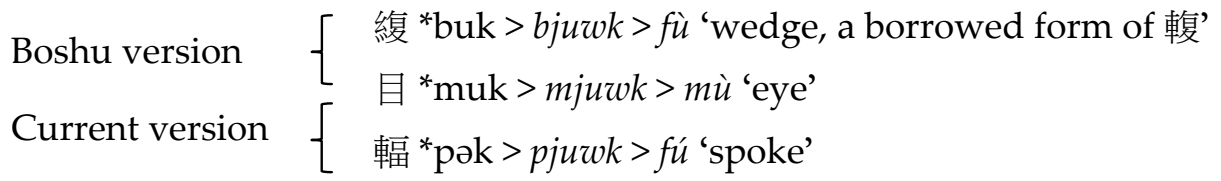


緮 fù rhymes with 目 mù in the Boshu version, and they have the same final in both Old Chinese and Middle Chinese. This situation is parallel with Dachu (大畜) in Shangbo and the current version (see table 4). Whereas 輻 fú and 目 mù in the current version do rhyme together in Middle Chinese but have different main vowels in Old Chinese, which indicates that * ${ }^{*}$ k had already assimilated into -juwk at the end of the Western Han period. The *-a (之) group

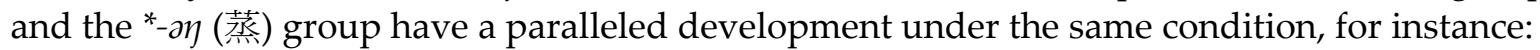

(5) 有 ${ }^{*}[\mathrm{G}]^{\mathrm{w}}$ ə? $>$ hjuwX > yǒu 'have, exist' 弓 * $\mathrm{k}^{\mathrm{w}}$ əท $>$ kjuwng $>$ gōng 'bow'

Such assimilation could be blocked by pharyngealization or medial *-r-, for instance:

(6) 怪 * ${ }^{\text {ws }}$ rə-s $>$ kweajH > guài 'strange'

洧 *[G] ${ }^{\mathrm{w}}$ rə? $>$ hwijX $>$ wěi 'name of a river'

The rhyming behavior of 輻 fú in the current version of Xiaochu (小畜) can be explained by the above phonological development. Namely, ${ }^{*}$-ək was assimilated into -juwk under the influence of a non-pharyngealized labial initial. After this happened, 輻 fú (MC pjuwk) and 目mù (MC mjuwk) could still rhyme together, since they have the same Middle Chinese final, which led to the change of rhyme word from 輹 fù to 輻 fú at that time. It may be therefore concluded that the rhyme word 輻 fú in the current version of Zhouyi reflects a phonological phenomenon of Early Middle Chinese. In the rhyming passage of Minming, Jiutan by Liu Xiang (劉向, 九嘆·壂命) “卻騏焂以轉運兮，騰驢驘以馳逐; 蔡女黜而出帷兮，戎婦入而綵繡服”，逐zhú rhymes with 服 fú, which also reflects assimilation *-ək > -juwk in late Western Han times:

(7) 逐 *lriwk > drjuwk > zhú 'pursue'

服 ${ }^{*}[\mathrm{~b}] \partial \mathrm{k}>$ bjuwk $>$ fú 'cloth'

The second issue is the assignment of -juwk (屋韻三等) characters after splitting up the traditional Jué (覺) group. This rhyme group includes Middle Chinese -owk (divison-I), -aewk (divison- II ), -juwk (divison-III) and -ek (divison-IV). According to the "front-vowel hypothesis" (Baxter 1992), two different main vowels must be reconstructed with front and non-front contrasts, namely, ${ }^{*}$-iwk and *-uk. Middle Chinese words in the -juwk rhyme group should be assigned to ${ }^{*}$-iwk or ${ }^{*}$-uk according to their rhyming or xiesheng behaviors. For instance:

(8) ${ }^{*} \mathrm{C}(\mathrm{r}) \mathrm{uk}>$ Cjuwk

畜 * ${ }^{\text {h } u k ~>~ x j u w k ~>~ x u ̀ ~ ' n o u r i s h ' ; ~ i t ~ r h y m e s ~ w i t h ~ *-u k ~ c a t e g o r y ~ w o r d s ~ i n ~ O d e ~ 188.2 A, ~}$ $202.4 \mathrm{~A}$; 蓄 $x \grave{u}$, 稸 $x \grave{u}$, and 慉 $x \grave{u}$, which share the same phonetic 畜 $x \grave{u}$ all belong to the *uk category.

(9) ${ }^{*} \mathrm{C}(\mathrm{r}) \mathrm{iwk}>$ Cjuwk

穆 *mriwk > mjuwk > mù 'harmonious'; it rhymes with *-iwk category words in Ode 282.1B.

In table 4, according to Baxter (1992) and Baxter-Sagart (2014)，輹 fù，复 fù，緮 fù，復 fù， 目 mù and 由 yóu all belong to the *-uk category, while 逐 zhú belongs to the *iwk category. Apparently, 逐 zhú is abnormal in this table. In both current and Boshu versions of Zhouyi, this abnormality repeats itself:

(10)初九：悔亡, 喪馬勿逐, 自復。見惡人无各。(The current version of Kui (睽) hexagram) "The first NINE, undivided, shows that (to its subject) occasion for repentance will disappear. He has lost his horses, but let him not seek for them - they will return of themselves. Should he meet with bad men, he will not err (in communicating with them)." 
It is well agreed among Qing scholars that 逐 zhú rhymes with 復 fù. However, 逐 zhú is replaced by 由 and 遂<逐> respectively in Shangbo and Boshu version, which is similar to the above situation in Dachu (大畜):

(11)初九：思(悔)亡=(亡，亡)馬，勿由(逐)，自腹(復)。見亞(惡)人无绺。 (Shangbo Kuí (楑(睽)， strip 32, refer to the previous translation).

(12)初九：鱼(悔)亡=(亡。亡)馬勿遂<逐>, 自復。見亞(惡)人, 无然。(Boshu Guai 乘(睽), upper line 75 , refer to the previous translation.)

The character 逐 zhú does not appear in the Shijing. However, there does exist a rhyme word 鿪zhú with 逐 zhú as phonetic:

(13)我行其野，言采其蓫。

昏姻之故, 言就爾宿。

爾不我畜，言歸思復。(小雅·我行其野二章, 188.2A)

"I travelled through the open country, luxuriant are the Rumex; with a view to (our) marriage, I went and lodged with you; but you did not cherish me, I go back and return (home)." 9

蓫 zhú rhymes with 宿 sù, 畜 $x \grave{u}$, and 復 fù in this stanza (188.2A); all rhyme characters belong to the traditional Jué (覺) group. Baxter-Sagart (2014)'s reconstructions are as follows:

Table 5. Rhyming situation of 鿪 in the Shijing (188.2A).

\begin{tabular}{|c|c|c|c|}
\hline & $\begin{array}{c}\text { Traditional } \\
\text { group }\end{array}$ & OC & MC \\
\hline 鿪 $z h u^{10}$ & Jué (覺) & *hlrjiwk ( ${ }^{*}$ lriwk) & drjuwk \\
\hline 宿 sù & Jué (覺) & ${ }^{*} \mathrm{~s}[\mathrm{u}] \mathrm{k}$ & sjuwk \\
\hline 畜 $x \grave{u}$ & Jué (覺) & ${ }^{*} \mathrm{q}^{\mathrm{h}} \mathrm{uk}-\mathrm{s}$ & xjuwX \\
\hline 復 fù & Jué (覺) & *m-puk & bjuwk \\
\hline
\end{tabular}

According to their reconstruction, 鿪 zhú is abnormal in the above table, parallel with the situation with 逐 zhú in Table 4, where *-uk and *-iwk categories were also mixed up. It is thus clear that both 逐 zhú and 鿪 zhú are rhyming with *-uk words in the Shijing and Zhouyi. Hence, we propose that the phonetic 逐 zhú should be assigned to the ${ }^{*}$-uk group in the Baxter-Sagart (2014) system:

(14)逐 *lriwk $\rightarrow{ }^{*}$ lruk $>$ drjuwk $>$ zhú 'pursue'

鿪 ${ }^{*}$ hlrjiwk ( ${ }^{*}$ lriwk) $\rightarrow{ }^{*}$ lruk $>$ drjuwk $>$ zhú 'sheep's-foot (name of grass)'

However, there is a case where 逐 zhú in the current version of Zhouyi became entangled with the *iwk category:

(15)六四:顛頣，吉，虎視䀓眝，其欲逐逐，无各。(The current version of Yí (頣) hexagram) "The fourth SIX, divided, shows one looking downwards for (the power to) nourish. There will be good fortune. Looking with a tiger's downward unwavering glare, and with his desire that impels him to spring after spring, he will fall into no error."

\footnotetext{
${ }^{9}$ This paper uses Karlgren (1974)'s English translation of Shijing.

${ }^{10}$ Baxter and Sagart (2014) do not include the item 鿪 zhú; Baxter (1992) reconstructs it as *hlrjiwk, which is equivalent to ${ }^{*}$ lriwk in their new system.
} 
We adopt the conclusion of Qing scholars' analyses that the Yí (頣) hexagram does not rhyme, apart from its first line statement ${ }^{11}$. The character 逐 zhú is replaced by 做 yōu and 笛 dí in Shangbo and Boshu versions respectively:

(16)六四：顛頤，吉。虎見(視)螒=(眜眝)，其猶(欲)敒=(逐逐)，亡(无)各。(Shangbo Yí (頣), strip 25, refer to the previous translation.)

(17)六四:顛頤，吉。虎視汇【=】(汇【汇】一眜【眝】)，其容(欲)笛=(笛笛一 逐逐)，无各。(Boshu Yí (頣), upper line 19, refer to the previous translation.)

We can conveniently join all the text variants of 逐 zhú in the following table:

Table 6. Text variants of 逐 zhú in the Yí (頣) hexagram.

\begin{tabular}{c|c|c|c}
\hline & $\begin{array}{c}\text { Traditional } \\
\text { group }\end{array}$ & Old Chinese & Middle Chinese \\
\hline 逐 $z h u ́$ & Jué (覺) & ${ }^{*}$ lriwk & drjuwk \\
\hline 做 yōu & Yōu (幽) & ${ }^{*}$ liw & yuw \\
\hline 笛 $d i ́$ & Jué (覺) & ${ }^{*}$ liwk12 & dek \\
\hline
\end{tabular}

It seems that the phonological status of the three versions of the Yi (頣) hexagram is somewhat identical: all the variants have a front vowel *-i. Note that this passage does not intend to rhyme, which might lower the standards for correspondences. Moreover, the characters in question actually form binomes, such as 逐逐, 做做 and 笛笛, which do not always faithfully reflect the phonological phenomena ${ }^{13}$. For instance, in the received version of Laozi (also called Wangbi version (王㢶本老子), we have 繩繩不可名; however, 繩繩 is replaced by the loan binome 蠅蠅 in the Xiang'er version (想爾注本), by 台微台微 in the Hanjian version (漢簡本) and by 尋尋 in the Boshu version (帛書本). Although all these binomes have similar syllabic structures as well as initials and main vowels, they do have quite different onsets or final consonants:

(18)繩繩 *Cə.ləท Cə.ləท *mə.ləท mə.ləy > shéngshéng “abundant”

蠅蠅 *m.rən m.rəy > yíngyíng “abundant”

台微台微 *ləməj ləməj $\rightarrow$ *ləm ləm > yíwēi yíwēi “abundant”

尋尋 *sə-ləm sə-ləm > xúnxún “abundant”

There are nine characters in the xiesheng series of 逐 zhú. According to the Guangyun shengxi (廣韻聲系), they could be divided into four groups: 1) drjuwk (直六切): 逐鱁䖶蓫䭼篴; 2) trhjuwk (丑六切): 鿪; 3) xjuwk (許竹切): 鿪; 4) dek (徒歷切): 笙. In Grammata Serica, Karlgren

11 “初九：舍爾靈龜，觀我朵頣。” “The first NINE, undivided, (seems to be thus addressed), 'You leave your efficacious tortoise, and look at me till your lower jaw hangs down.' There will be evil.” Gu Yanwu (顧炎武), Duan Yucai (段玉裁) and Wang Niansun propose that 龜 $g u \bar{\imath}$ rhymes with 頣 yí, while Jiang Yougao (江有誥) believes there is no rhyming. Here we follow Gu, Duan and Wang's analyses.

12 Baxter and Sagart (2014) have not reconstructed the item 笛 di; however, the character 迪 di with the same Middle Chinese reading as笛dí is reconstructed as *liwk in Baxter (1992). We provisionally assume that 笛díand 迪 di had the same pronunciation in Old Chinese.

13 迪 dí rhymes with 復 *m-puk > fù, 毒 *m-[d] ${ }^{*} u k>d \dot{u}$ in 257.11A (大雅·桑柔); 迪 $d \dot{\imath}$, 復 fù and 毒 $d \dot{u}$ are assigned to the traditional Jué (覺) group. However, after the split of Jué (覺) by Baxter and Sagart (2014), 迪 dí is assumed to have had a different main vowel from 復 fù and 毒 dú. A probable explanation is that 迪 dí might come from a late version of the Shijing. 
recorded three characters (GSR 1022): 逐 drjuwk > zhú, 篴 $d e k>z h u ́$, and 鿪 trhjuwk > zhú. However, according to the Guangyun (廣韻), 策 zhú is equivalent to 笛 $d i$ 'CChinese flute', which was invented in the middle of the Western Han period (around 157-87 BC) ${ }^{14}$. Hence, the pronunciation of division-IV word 篴 dek $>$ zhú might be of late origin and should not be used as evidence to reconstruct Old Chinese front vowel ${ }^{*}$ i.

\section{References}

Baxter, William. 1992. A Handbook of Old Chinese Phonology. Mouton de Gruyter.

Baxter, William, Laurent Sagart. 2014. Old Chinese: A New Reconstruction. Oxford University Press.

Duan, Yucai (段玉裁). 1988. Liushu Yinyun Biao 六書音均表 [Phonological Tables of the Liushu], in Shuowen Jiezi Zhu 说文解字注 [Annotations of Analytical Dictionary of Characters]. Shanghai: Shanghai guji chubanshe 上海: 上海古籍出版社.

$\mathrm{Gu}$ ，Yanwu (顧炎武). 2012. Ri Zhi Lu 日知錄 [Records of Daily Knowledge]. Shanghai: Shanghai guji chubanshe 上海: 上海古籍出版社.

Han, Ziqiang (韓自強). 2004. Fuyang Hanjian Zhouyi Yanjiu 阜陽漢簡周易研究 [Study of the Fuyang Zhouyi]. Shanghai: Shanghai guji chubanshe 上海: 上海古籍出版社.

Jiang, Yougao (江有誥). 1993. Yinxue shi shu 音學十書 [Ten Books on Old Chinese Phonology]. Beijing: Zhonghua shuju 北京: 中華書局.

Karlgren, Bernhard. 1974. Book of Odes (Chinese text, transcription and translation). The Museum of Far Eastern Antiquities.

Legge, James. 2013. I Ching (Book of Changes). Kessinger Publishing.

Ma, Chengyuan (馬承源). 2003. Shanghai Bowuguan Cang Zhan'guo Chu Zhushu上海博物館藏戰國楚竹書(三). [Shanghai Museum Collection of Chu Bamboo Books from the Warring States Period (III)]. Shanghai: Shanghai guji chubanshe 上海: 上海古籍出版社.

Qiu, Xigui (装錫圭). 2014. Mawangdui Hanmu Jianbo Jicheng 馬王堆漢墓簡帛集成[Integration of Bamboo Slip and Silk Documents in Mawangdui Han Tomb]. Beijing: Zhonghua shuju.

Shen, Jianshi (沈兼士). 1985. Guangyun shengxi 廣韻聲系 [The Xiesheng system of Guangyun]. Beijing: Zhonghua shuju.

Ма Кунь. Исследование фонологических проблем в вариантах текста гексаграмм сяочу и дачу («Книга Перемен»)

В статье обсуждаются вопросы фонологической реконструкции ряда древнекитайских слов, встречающихся в гексаграммах Сяочу (小畜) и Дачу (大畜) «Книги перемен» с привлечением новых данных, полученных по трем альтернативным версиям памятника, найденным в результате археологических раскопок. Обосновывается гипотеза, что необычная рифмовка между знаками 輻 fú 'колесничная спица' и 目 тѝ 'глаз', наблюдаемая в канонической версии Сяочу, вызвана фонетической ассимиляцией. Также высказано предположение, что фонетик 逐 zhú 'преследовать' необходимо отнести к группе рифм *-uk вместо *-iwk, как это предложено в системе Бэкстера и Сагара (2014).

Ключевые слова: древнекитайский язык; гексаграммы Ицзина; китайская система рифм; фонологическая реконструкция.

14 《廣韻·錫韻》: “笛, 樂器。《風俗通》云武帝時丘仲所作也。晉協律中郎列和善吹笛也。出《周禮》。” 